\title{
Stakeholders' Awareness Level for Greening Project Initiatives in the Federal University of Technology, Akure, Nigeria
}

\author{
Olaoluwa Paul AASA* \\ Olalekan Aquila JESULEYE \\ Department of Management Technology, School of Management Technology, \\ The Federal University of Technology, Akure, P.M.B 704, Ondo State, Nigeria
}

\begin{abstract}
Environmental awareness is a key to promoting greening initiatives within the university campus. People who have environmental awareness are conscious of the footprint they leave on the environment. The study combines participatory action research with survey design to investigate the stakeholders' awareness level for greening project initiatives in the Federal University of Technology, Akure, Nigeria. A sample size of 386 comprising the proportions of three stakeholders - staff, students and commercial service providers were purposively selected and used for the study. Primary data were collected using a structured questionnaire with acceptable reliability of 0.930 . The study found that 70 per cent of the university stakeholders are largely familiar with the term 'environmental protection or sustainability'. Using Relative Frequency Index, it was discovered that campus stakeholders often perform/use latent greening activities involving efficient transportation (0.671), efficient energy (0.795) and waste management (0.692) consciously or otherwise. Further analysis involving Environmental Awareness Index (EAI) showed that the level of awareness for greening project implementation from the three dimensions (environmental motivation, knowledge and skills) is highest among the staff $(0.823)$, followed by students $(0.770)$ and commercial service providers $(0.769)$ respectively. Kruskal-Wallis test showed a statistically insignificant difference in the level of awareness for greening project implementation among major stakeholders in the study area $\left(\mathrm{X}^{\wedge} 2\right.$ $(n=330)=3.909, p=.142)$. Consequently, the study recommended the implementation institution-wide policy supported by awareness creation among stakeholders to foster both individual and institutional levels commitments. Keywords: Greening Project, Environmental Awareness Index, Relative Frequency Index, University Campus, Stakeholders
\end{abstract}

DOI: $10.7176 / \mathrm{JRDM} / 66-06$

Publication date:June 30th 2020

\section{Introduction}

There is a growing consensus of opinions that framework offered by sustainable development cannot only be a matter of concern at the governmental level but also all institutions need to take an active role in the struggle, being part and contributors to this environmental footprint (Filho et al, 1996). Educational institutions are keys to bringing about a change. It is very important for any individual's success in life. It provides skills that prepare an individual physically, mentally and socially confident to solve many problems in the society (Jadhav, Jadhave \& Raut, 2014). With this knowledge, universities are keying into efforts at reducing their environmental impact through greening initiatives. Universities around the world have attempted to transform their campuses to make them greener (Tiyarattanachai \& Hollmann, 2016). Universities combine learning, research and practices that promote environmentally friendly initiatives. Global University Network for Innovation (GUNI) observed that greening project on university campuses occurs in various ways categorized into research, curricula, community engagement, and facilities operations (GUNI, 2012).

Its objective is the minimization of negative environmental, economic, societal and health effects in the use of resources. Performing their role as think tank and model of the world require awareness by all stakeholders within the university community. This is because attitudes are related to behaviour and actions (Raderbauer, 2011), Thus, several scholars have called for a more inclusive and "whole-of-university" approach to achieving sustainability and to rethink how higher education can address sustainability issues not only within the curriculum and research but also via community outreach, collaboration, as well as through the participation of the various university stakeholders (Wright, 2002; Beringer, Adomßent, 2008; McMillan, Dyball, 2009).

Environmental awareness is a key to promoting greening initiatives within the university campus. It is the reaction of an individual or group or society to environmental problems with acts and thought for its protection (Akkor \& Gunduz, 2018). It makes community members realize the impact they leave on their environment while carrying out daily activities to change their behaviour that has become a norm. People who have environmental awareness are the ones who use the method of producing product or rendering services or consuming resources with the least negative result on the environment. Awareness in the university setting is gained through the provision of relevant education to students and members of staff to enhance the implementation and performance of greening (Dookhitram, Narsoo, Sunhaloo \& Sukhoo, 2012). Environmental sustainability awareness is one of the prerequisites for environmental attitude and behavioural change in caring for the natural environment in the 
face of impending climate change and global warming (Dookhitram, et al., 2012; Hamid, Ijab, Sulaiman, Anwar \& Norman, 2017; Siwaporn, Vilas, Brahmanand \& Chettiyappan, 2017). If indifference was reported by Filho, Shiel, Paco \& Brandli (2015) to be a barrier to overall greening performance, lack of environmental awareness (indifference but also lack of understanding) will reduce the tendency to reap the benefits inherent in the implementation of the greening project, including saving money by decreasing wasteful practices and reducing the consumption of resources to mention a few.

Increased empirical research examining environmental sustainability in higher institutions have shown numerous efforts being made world-wide (Cole, 2003; Dookhitram, et al., 2012; Jadhav, et al., 2014; Ramesh, 2017). Much has not been reported about Nigerian universities' commitment to greening project unlike some African countries like South African and Egypt have been able to develop workable frameworks that help in the implementation. Nigeria is not an exception. Abubarkar, Al-Shihri and Ahmed (2016) observed that in few universities in developing countries where attempts are made to implement sustainable initiatives, performance is low even at the national level. For example, Nigeria still ranked low in term of environmental rating. Environmental Performance Index (CEPI) for Nigeria in 2016 was at 58.6, ranking 133 out of 190-member countries of UN; behind African countries like Egypt (66.45), South Africa (70.52), Namibia (70.84) and Kenya (62.49) (Revised National Policy on Environment, 2016). Nigerian universities appear to be lagging in the implementation of greening policy (if they have any) instead of championing the course. This is due to a lack of synergy and involvement of relevant stakeholders who are probably not conscious of the impact of their actions and inaction on the environment let alone implementing greening initiatives. Moderate to a low level of awareness on greening among stakeholders can result in poor performance (Dookhitram, et al., 2012; Oyelude \& Alabi, 2013). This could be the major clog in university environmental performance since the latter can change attitude and behaviour, leading to accrued economic, social and ecological benefits. It is, therefore, a necessity, to study the awareness level of campus stakeholders about how a much higher educational institution can contribute to environmental imbalance and their orientation towards existing latent greening initiatives. The specific objectives are to:

i. $\quad$ assess the familiarity of campus stakeholders on the 'greening' and its related terms;

ii. examine the frequency of participation of campus stakeholders in greening activities; and

iii. investigate the level of awareness for greening project initiatives among campus stakeholders in the study area.

The only hypothesis tested in the study is presented below.

H01: There is no significant difference in the stakeholders' awareness level for greening project initiatives in the study area.

\section{Review of Related Literature \\ 2.1 Concept of Greening}

University Greening is an action phrase that connotes 'greening of a university'. A university that is undergoing this action is said to be green. A green university can be said to be sustainable in a broad term. The latter (sustainability) and other related term have assumed different meaning by different individual or organization. There has been a reference to sustainability in three dimensions-social, economic and environmental but sustainability concerning greening is associated with environmental concern. Describing 'sustainable university', Mruszczyk, et al (2009) explained that such university, "is one that promotes sustainability in all sectors of higher education including operations, governance, curriculum, research and outreach; while strengthening its capacity through learning, practice and collaboration. Similarly, the implementation of environmental sustainability on campuses was initially coined as "greening the campus", with most attention on procurement/purchasing and facilities management, where the focus is on the management of resource use (energy, water, paper), emission of pollution (solid waste, water and air discharges), and maintenance of biodiversity (management of open space, waterways) (Ian, 2006). Greening of Higher Education, as defined by Creighton (1999), is "the process of reducing the multitude of on and off-site environmental impacts resulting from campus decisions and activities, as well as raising environmental awareness with human communities of college or university.

A sustainable or green campus is hooked on the collaboration of campus users (students, employees and a lot of visitors.) who must be willing to change their behaviour to achieve the goal of the institution in this area. At the same time, sustainable solutions on campus can influence the behaviour of these users outside the campus - at home or their other employer's offices - now and in the future (Heijer, Teeuw \& Aalbers, 2010).

Since sustainability on a university campus has mainly focused on environmental management of campuses, Ian (2006) observed that green universities among other things must:

seeks to abate its consumption of resources by putting in place measures to conserve water, energy and paper, etc; cuts waste output through a process of reducing consumption and reusing materials via recycling where possible; makes purchasing decisions based on knowledge of the environmental and social impacts of the product, e.g. paper manufactured from sustainably managed forests; 
encourage environmentally preferred transport options such as car-pooling, bicycle facilities, public transport facilities and staff incentives to discourage car-based travel engages staff and students and supports them to continually improve environmental practices and reduce their negative environmental impacts;

ensures that any maintenance and construction is carried out to minimize environmental impacts and constantly improves the environmental performance of the university facilities; and makes decisions about financial investments and research with consideration given to the social and environmental implications of those decisions.

\subsection{Environmental awareness}

Environmental awareness and sustainability are both environmental, ethical and social issues (Deniz, 2016). Environmental awareness is the reaction of an individual or group or society to environmental problems with acts and thought for its protection (Akkor \& Gunduz, 2018). Kokkinen (2013) defined it as "a state of being aware, having knowledge about, and being conscious of the external surroundings in which people live and work, and which tend to influence people's development and behaviour". It makes community members realize the impact they leave on their environment while carrying out daily activities to change their behaviour that has become a norm. Awareness about the environment helps the individuals to understand the impact we cause on our earth thereby helping us to find ways to keep our surrounding clean and green. It develops the ability to think about the proper management of our resources (Sahu, Roy \& Rajkiran, 2015). Environmental awareness is an important condition for preventing environmental pollution and promoting environmental friendly attitudes involving all members of the society (Akko \& Gunduz, 2017).

The concept is multidimensional in that it can be measured using a combination of variables. It is commonly associated with pro-environmental knowledge, pro-environmental values, and pro-environmental attitudes which are its most frequently mentioned components as identified by (Bamberg (2003) and referenced by Fu, Zhang and Bai (2018). However, in this study environmental awareness is described as a combination of motivation, knowledge and skills based on the model developed (Kokkinen, 2013; Harju-Autti, 2013). Ijab, et al. (2017) identified the following as being key to environmental awareness in the university:

Knowledge about the greening issue is created through the education system and that this is very important if the university is serious in implementing green initiatives.

Participation of all stakeholders in higher education, where the initiative takes place is sacrosanct for its effectiveness.

Putting in place various kinds of implementation programmes targeted for everybody in with the university community, with special attention on future decision-makers, the students.

During the implementation of greening, the motives and benefits of the exercise must be clearly explained to the participants in a clear term. The goals, strategies and expected outcomes from the implementation need to be communicated to the students and staff to provide them with the motivation and understanding of why greening the environment is a necessity.

Finally, environmental sustainability and its awareness activities via campaigns require systematic planning, implementation and means of tracking effectiveness must be put in place.

\subsection{Empirical Review}

Dookhitram et al (2012) conducted an awareness survey on green computing among University of Technology, Mauritius students. Questionnaire of 56 items was distributed to 45 students to get results from the study after analyzing the data using descriptive statistical tools of frequency and percentage. The results show that students have moderate knowledge about green computing but their everyday green computing practices are not satisfactory. They also perceived that the students surveyed intend to adopt green computing for the benefit of the environment and their future.

Sivamoorthy, Nalini, and Kumar (2013) evaluated environmental awareness and practices relating to various factors like causes of pollution, conservation of soil, forest, air, etc., energy conservation, conservation of human health, conservation of wildlife and animal husbandry. They also discuss environmental practices among college students about the usage of plastic and its disposal, alternative for plastic, toilet usage, its use in the cultivation of saplings, rainwater harvesting and also their participation in environment-related programmes. The target for their study was college students as environmental education is part of their curriculum. The study was quantitative using a self-prepared questionnaire on environmental practices. Multi-stage sampling technique was adopted. The level of awareness was generally high among the respondents but in practice, males were more involved than females. Since awareness has been shown in earlier literature to be important for efforts needed for community engagement, Ngniatedema and Li (2014) investigated the influence of green operations on organizational performance for the top 500 publicly traded companies in the US. Using environmental impact criteria and green reputation, manufacturing companies scored lower on the environmental impact metric ladder and higher on the green reputation metric than companies in services industries. Besides, the overall impact of green operations was found to be different between the manufacturing and service firms studied. For manufacturing firms, environmental 
impact score and green policies and performance score were found to have an impact on organizational performance while green reputation plays a more important role in impacting the organizational performance of service firms.

Ramesh (2017) analyzed awareness about green campus opportunities amongst the educational institutions of North Karnataka. The work used a questionnaire guide with 20 questions to exploring the awareness about the green campus concepts among 40 colleges in the study area. The questionnaires were filled by the researcher through close interaction with the management members, principals and teachers of the institutes. Depending on descriptive data analysis techniques to analyze the data collected, the result shows fair awareness level of green campus in the areas of water and waste management, renewable energy, green building, paperless office and Wifi Campus. It was anticipated that human behaviour, including politics, may prove to be a bigger stumbling block than a lack of technological advances.

Akkor and Gunduz (2018) piloted a study to detect the attitude and behaviour levels of university students in Northern Cyprus about environmental education. The research population consists of the university students in Northern Cyprus, while the sample consists of 175 university students in Northern Cyprus in the same year. A questionnaire with "environmental awareness scale" and "environmental attitude scale" was administered to the participants as data collection tools. The responses were analyzed quantitatively using T-test and ANOVA. Female students were observed to have higher environmental attitudes and they are more sensitive to the environment than male students though the environmental awareness was generally low which supports some previous studies on the subject matter. They recommended early environmental awareness education from pre-school level for sustained attitude and behaviour of students up to university level.

There exist some studies on awareness level on greening, both within the campus environment (Robert, et al., 2010; Dookhitram et al., 2012; Sivamoorthy et al., 2013) and outside (Dahle \& Neumayer, 2001; Oyelude \& Alabi, 2013; Ngniatedema \& Li, 2014) as found in the literature. They show that generally, awareness ranges from low to moderate. It was, however, noted that most of the studies focus on single stakeholder. Where there seems to be comparison on awareness level, it exists based on the categorization of single stakeholder, i.e. student (male and female) (Sivamoorthy et al., 2013). Therefore, it can be said that very few empirical studies exist on the assessment of awareness using multiple stakeholders. Furthermore, there has not been uniformity on the indicators for measuring awareness level on greening.

\section{Methodology}

The study was intended to promote joint action for environmental management in a typical university campus. Therefore, the study combined participatory action research with survey design to achieve this objective through the generation of environmental knowledge. A survey design was used to collect data on the characteristics and opinions of major stakeholders in the Federal University of Technology, Akure, Nigeria. The stakeholders include: are students, staff and commercial service providers. A sample size of 386 derived using Krejcie and Morgan (1973) table and proportionately distributed among the respondents as shown in Table 1 were selected from a population of 21,512. A questionnaire was the primary sources of data collected from the identified stakeholders after its development from the literature was the source primary data. The instrument has four sections which solicited responses from respondents on their demographic characteristics, familiarity with the term 'greening' or 'environmental sustainability/ protection', frequency of participation in greening activities and environmental awareness. The variables involved in the study and the type of data collected are presented in table 2 .

The researcher personally distributed some of the research instruments while others were distributed by students and colleagues in other departments in the institution. This was responsible for the high response rate of 85.5 per cent as presented in table 3. Data were analyzed using both descriptive - frequency and percentage distributions, Relative Frequency Index (RFI) and Environmental Awareness Index and inferential statistics Sample t-test and Kruska Wallis H Test.

Table 1. Population and sample size

\begin{tabular}{|l|r|r|r|}
\hline Stakeholders & Population & Proportion & Sample Size \\
\hline Students & 19,141 & 0.890 & 335 \\
\hline Staff (Academic Staff \& Non-academic) & 2,321 & 0.110 & 41 \\
\hline Commercial service providers & 50 & 0.002 & $1(10)$ \\
\hline Total & 21,512 & 1.000 & $377(386)$ \\
\hline
\end{tabular}


Table 2 Design of questionnaire

\begin{tabular}{|c|c|c|c|}
\hline Part & Variable & Type of data & Description \\
\hline A & \begin{tabular}{ll}
\multicolumn{2}{l}{ Socio-demographic Data } \\
- & Gender \\
- & Category of Respondent \\
- & Level (for students) \\
- & Department/Unit \\
\end{tabular} & Nominal/Categorical & $\begin{array}{l}\text { Option based on categories } \\
\text { of each item }\end{array}$ \\
\hline B & $\begin{array}{l}\text { Familiarity with 'greening' or } \\
\text { 'environmental sustainability/ protection' }\end{array}$ & \multirow{3}{*}{$\begin{array}{c}\text { Ordinal } \\
\text { (Five-point Likert } \\
\text { scale) }\end{array}$} & $\begin{array}{l}\text { 1(Strongly disagree) to } 5 \\
\text { (Strongly agree) }\end{array}$ \\
\hline $\mathrm{C}$ & $\begin{array}{l}\text { Frequency of participating in greening } \\
\text { activities }\end{array}$ & & 1(Never) to 5 (Always) \\
\hline $\mathrm{D}$ & Awareness Level on Greening Project & & $\begin{array}{l}1 \text { (Not at all aware) to } 5 \\
\text { (Very much aware) }\end{array}$ \\
\hline
\end{tabular}

\section{Results and Discussion}

\subsection{Response rate}

Based on the sample size calculated in chapter three, a total of three hundred and eighty-six (386) respondents comprising of three hundred and thirty-five (335) students, forty-one (41) staff and ten (10) commercial service providers were targeted for the distribution of questionnaires. Three hundred and thirty (330) responses were retrieved and used to arrive at the findings of the study. As presented in Table 4.1, each group of stakeholders have 80.0 per cent and above response rates. Specifically, students, staff and commercial service providers groups have 86.0 per cent, 82.9 per cent and 80.0 per cent response rates. The overall response rate was 85.5 per cent. Saldvar (2012) stated that the response rate of between 80-85 per cent is good for survey involving person-to-person distribution. Students who served as research assistants contributed to the high response rate recorded in this study, most importantly the distribution of a questionnaire to students.

Table 3: Survey response rate

\begin{tabular}{|l|r|r|r|r|}
\hline Stakeholders & $\begin{array}{r}\text { Proposed } \\
\text { questionnaire } \\
\text { responses }\end{array}$ & $\begin{array}{r}\text { Retrieved } \\
\text { responses }\end{array}$ & $\begin{array}{r}\text { Percentage } \\
\text { based on } \\
\text { stakeholders (\%) }\end{array}$ & $\begin{array}{r}\text { Percentage in total } \\
\text { response (\%) }\end{array}$ \\
\hline Students & 335 & 288 & 86.0 & 87.3 \\
\hline $\begin{array}{l}\text { Staff (Academic Staff } \\
\text { \& Non-academic) }\end{array}$ & 41 & 34 & 82.9 & 10.3 \\
\hline $\begin{array}{l}\text { Commercial service } \\
\text { providers }\end{array}$ & 10 & 8 & 80.0 & 2.4 \\
\hline Total & 386 & 330 & 85.5 & \\
\hline
\end{tabular}

\subsection{Socio-demographic Characteristics}

As presented in Table 4, male respondents have the highest representation of 67.3 per cent while their female counterparts accounted for the remaining 32.7 per cent of the respondents. This does not mean that there are more male students, staff and commercial service providers on FUTA campus. The study ensures the two genders were considered during the distribution of research instruments. The students' respondents spread across schools within FUTA campus namely, School of Agriculture and Agricultural Technology (SAAT), School of Computing (SOC), School of Engineering and Engineering Technology (SEET), School of Earth and Mineral Science (SEMS), School of Environmental Technology (SET) and School of Health and Health Technology (SHHT). Others are School of Management Technology (SMAT), School of Science (SOS), and School of Postgraduate Studies (SPGS). Since the number of questionnaires administered in each school was based on their proportions in the sample size for the students as calculated in Table 1, the number of copies of the questionnaire distributed and retrieved are not the same. Table 4.2 reveals that those in SOS have the largest representation of 22.6 per cent while those in SAAT, SEET, SET, and SMAT were in percentages, 14.2, 10.4, 16.3 and 15.3 respectively. Those in SHHT, SOC and SPGS were in percentages 5.9, 5.2 and 4.9 respectively. Most of these students (89.2 per cent) were in year three in their various departments while only 10.8 per cent belong to other levels. Also, Table 4 illustrates that 11.4 per cent of the sampled FUTA staff have been on the campus for more than 10 years. Those within 7-10 years on the campus were 5.9 per cent, just as 14.7 per cent have worked on the campus between 4-6 years. However, more than 50 per cent of FUTA staff (58.8 per cent) have worked for 1-3 years. It appears learning about one's environment does not require long years to do so given one's interest in promoting a healthy work environment. Lally, et al., 2010 stated that it may take 18-254 days to master a behaviour. Lally further observed that acting for the first time requires planning, even if plans are formed only moments before the action is performed and attention. 
This suggests that deliberate act to learn about once the environment is much more important than the length of time required.

Table 4: Survey respondents' socio-demographic characteristics

\begin{tabular}{|c|c|c|}
\hline Characteristics & Frequency & Per cent \\
\hline \multicolumn{3}{|l|}{ Gender } \\
\hline Male & 222 & 67.3 \\
\hline Female & 108 & 32.7 \\
\hline Total & 330 & 100.0 \\
\hline \multicolumn{3}{|l|}{ Students' level } \\
\hline 300 & 257 & 89.2 \\
\hline Others & 31 & 10.8 \\
\hline Total & 288 & 100.0 \\
\hline \multicolumn{3}{|l|}{ Students' school } \\
\hline SAAT & 41 & 14.2 \\
\hline SEET & 30 & 10.4 \\
\hline SEMS & 15 & 5.2 \\
\hline SET & 47 & 16.3 \\
\hline SMAT & 44 & 15.3 \\
\hline SOS & 65 & 22.6 \\
\hline SHHT & 17 & 5.9 \\
\hline SCOM & 15 & 5.2 \\
\hline SPGS & 14 & 4.9 \\
\hline Total & 288 & 100.0 \\
\hline \multicolumn{3}{|c|}{ Staff years of experience } \\
\hline$<1$ year & 3 & 8.8 \\
\hline 1-3 years & 20 & 58.8 \\
\hline 4-6 years & 5 & 14.7 \\
\hline $7-10$ & 2 & 5.9 \\
\hline$>10$ & 4 & 11.8 \\
\hline Total & 34 & 100.0 \\
\hline
\end{tabular}

\subsection{Familiarity with the term 'greening' and other related terms}

The respondents were asked whether they are familiar with the term 'greening' or 'environmental sustainability/protection'. Their responses as presented in Table 5 indicates that more than 70.0 per cent ( 70.9 per cent) have come across or heard about the terms before while less than 30.0 per cent (29.1 per cent) seems not to be conversant with the term. There is an indication that not less than 70 out of every 100 stakeholders on FUTA campus are familiar with the term which means environmental protection is not completely alien to the university community. Musa, Buniamin, Johari, Ahmad, Rauf and Rashid (2013) believed that the main key indicator that will lead to a successful implementation of green practices is familiarity with related policies. This is to acquaint stakeholders about the contents of such policies as it relates to them and their organization but also knowledge creation which is fundamental to acquisition of skills for the purpose.

Familiarity with the terms does not necessarily translate into knowing what it is all about. The study proceeded further to seek the level of agreement of respondents on the definition of 'campus greening'. As presented in Table 5, 44 per cent and 46.6 per cent of the stakeholders that indicated that they are familiar with the term strongly agreed and agreed respectively that the definition presented in the questionnaire adequately captures the meaning of campus greening. Since they are above 90 per cent, it can be said that many of the respondents that indicated familiarity with the term knows its meaning. To a great extent, the stakeholders agreed with Creighton (1990) that greening must necessarily reduce the enormous environmental impacts resulting from activities going on any human community and should involve raising environmental awareness in the same. Achieving this objective through behavioural change requires joint action among campus participants (Heijer et al., 2010). 1.3 per cent of the respondents were not convinced about the definition, while 8.1 per cent were unsure about the correctness of the definition. Notwithstanding the foregoing, it can be said that all stakeholders sampled are now aware of the definition of the term as stated in the questionnaire and should be able to convey the information to those who are not familiar with the concept when the need arises. 
Table 5: Meaning of campus greening

\begin{tabular}{|l|r|r|}
\hline \multicolumn{2}{|c|}{ Frequency } & Per cent \\
\hline Familiarity with the term, 'Greening' or 'Environmental Sustainability/Protection' & 234 & 70.9 \\
\hline Yes & 23 & 29.1 \\
\hline No & 96 & $\mathbf{1 0 0 . 0}$ \\
\hline Total & $\mathbf{2 3 4}$ & \\
\hline Yes, my level of agreement is here indicated & 103 & 44.0 \\
\hline Strongly agree & 109 & 46.6 \\
\hline Agree & 19 & 8.1 \\
\hline Neutral & 2 & 9 \\
\hline Disagree & 1 & 4 \\
\hline Strongly Disagree & $\mathbf{2 3 4}$ & $\mathbf{1 0 0 . 0}$ \\
\hline Total & & \\
\hline
\end{tabular}

\subsection{Frequency of participation in some greening activities}

To further identify and familiarize stakeholders with activities that can be identified with greening, the study sought to know how often they participated in some greening activities within the last few months (less than a year). In line with the scope of this study, the activities were categorized into: efficient transport, power/energy-saving and resource-saving/ waste management in the questionnaire. They were depicted using different font styles to capture the attention of respondents. For instance, efficient transport activities were stated using 'normal/usual font', energy savings activities were 'underlined' while waste management activities were in italics. The frequency distribution for each of the activities is presented in Table 6.

4.4.1 Frequency of efficient transportation usage

Generally, all the stakeholders 'always' walk within the campus especially short distances (0.867), they 'often' take public or mass transit to/from work $(0.712)$ and telecommute or work from home as part of their working day from their personal computers $(0.603)$. Web conferencing $(0.504)$ was 'sometimes' done when necessary. Students in most cases walk within the campus except when they need to commute from one extreme part of the campus to another (i.e. from Obakere campus to Obanla campus or North gate Hostel area). There are also few occasions when they need to enter bus or tricycle to catch up with a class at another venue on campus when it is apparent they are likely to get to such class late. Members of staff are more involved in on-campus commuting among the three stakeholders. Some staff drive to lecture and other meeting venues from their offices.

While some use personal means of commuting, others (for example staff whose work involves dispatching mails) do so by using utility and official vehicles. The advantage of using a utility vehicle is that as much as four or five personnel can be transported to different areas of work at the same time rather than going individually using personal means of commuting. Commercial service providers are less involved in commuting on campus. Most times they remain in their shops to attend to their customers until closing time. Akinbamijo and Osunsanmi (2007) observed that the greater the accessibility, the lower the need for transport such that transport planning will be environmentally friendly if it looks beyond road expansion or elongation. They further stated that new peripheral layouts should be planned based on vehicle-free concepts whereby people and needs are brought close to one another via vehicle free neighbourhood planning, along with bicycle and pedestrian-friendly provisions on the layout.

4.4.2 Frequency of power/energy saving

Stakeholders opined that they 'always' use only essential electrical appliances when there is electricity supply (0.828). The respondents also opined that they 'often' switch off electronics and appliances when not in use (0.790), use energy-saving bulb and other devices (0.783), and turn off lighting devices and electronics when not in use (0.779). Many individuals especially those that stay off-campus who use prepaid electricity meters are forced to engage in these practices because the more appliances they use, the more the unit of electricity they use and pay for. Some become adapted to this way of life to such extent that they practice the same in their workplace or school. Also, the school authority has made it mandatory for staff to switch off office electrical appliances and electronics when leaving the office for saving energy and preventing fire accident. However, this does not mean there are not few instances when people forget to switch off office electrical appliances and electronics, which means something, must be done to ensure full compliance most especially in students' hotels.

4.4.3 Frequency of resource-saving/ waste management

Avoiding the purchase of a daily newspaper (0.798), using soft copy documents rather than printed copy when appropriate (0.768), repair and reuse of instead of throwing away (0.745) and printing double-sided (0.682) were 'often' used to save resources or manage waste in the last few months. These activities apart from helping to manage resource usage will also reduce the amount spent on the purchase of those materials. The practice of communicating through paper mails is still very common in offices, departments and staff. The decision body of 
the university, the University Senate is showing a sustainable example as communications among members is done via the official university e-mail. This is being replicated in some schools that need to communicate with members on the Board of Studies. Furthermore, eating at fast-food restaurants rather than take-away (0.583) and recycle or reuse of paper or any other materials $(0.583)$ are 'sometimes' used to save environmental resources in comparison with others.

Generally, these activities whether efficient transportation usage, power/energy saving or resource-saving/ waste management are still being carried out at minima level since many campus stakeholders at the individual level are still not very much aware of the inherent benefits to the physical environment. This supports the argument of Oyelude and Alabi (2013) that some organizations implement greening initiative at a minimal level because they are not conscious of their benefits to the environment. In the same line of thought, Aziz et al. (2018) showed that the extent of green initiative adoption in some public corporations is rather to a certain extent in the areas of waste management, recycling, energy-saving, among others but are not proactive.

Table 6. Frequency of participation in some greening activities

\begin{tabular}{|c|c|c|c|c|c|c|}
\hline & \multicolumn{5}{|c|}{$\begin{array}{l}\text { \% distribution of Likert } \\
\text { responses }\end{array}$} & \multirow[t]{2}{*}{ RFI } \\
\hline & 1 & 2 & 3 & 4 & 5 & \\
\hline \multicolumn{7}{|l|}{ Efficient transportation } \\
\hline Carpooling or taking public or mass transit to/from work & 10.0 & 15.2 & 14.8 & 28.8 & 31.2 & 0.712 \\
\hline $\begin{array}{l}\text { Telecommuting or working from home as part of your working day } \\
\text { from your PC }\end{array}$ & 15.5 & 16.4 & 32.4 & 22.7 & 13.0 & 0.603 \\
\hline Video and/or web conferencing & 31.5 & 22.7 & 20.0 & 13.9 & 11.8 & 0.504 \\
\hline Walking within the campus especially short distances & 1.2 & 2.7 & 14.8 & 23.6 & 57.6 & 0.867 \\
\hline \multicolumn{7}{|l|}{ Power/energy saving } \\
\hline Energy-saving bulb and other devices & 3.9 & 7.6 & 22.1 & 25.8 & 40.6 & 0.783 \\
\hline Switching off electronics and appliances when not in use & 2.4 & 6.1 & 26.4 & 24.5 & 40.6 & 0.790 \\
\hline Turn off lights and electronics when not in use & 3.0 & 7.0 & 25.8 & 25.8 & 38.5 & 0.779 \\
\hline $\begin{array}{l}\text { Using only essential electrical appliances when there is an electricity } \\
\text { supply }\end{array}$ & 1.8 & 5.8 & 17.3 & 27.0 & 48.2 & 0.828 \\
\hline \multicolumn{7}{|l|}{ Resource savings or waste management } \\
\hline Avoid purchasing a daily newspaper (I use Internet/TV instead) & 5.5 & 7.9 & 16.4 & 23.0 & 47.3 & 0.798 \\
\hline Do not throw away items which could be repaired or reused & 4.5 & 9.4 & 27.0 & 27.3 & 31.8 & 0.745 \\
\hline Eating at fast-food restaurants rather than take-away & 16.4 & 22.7 & 27.9 & 19.1 & 13.9 & 0.583 \\
\hline Printing double-sided & 7.3 & 13.9 & 30.3 & 27.3 & 21.2 & 0.682 \\
\hline Recycle or reuse of paper or any other materials & 15.5 & 24.2 & 27.9 & 19.1 & 13.3 & 0.581 \\
\hline Soft copy documents rather than printed copy when appropriate & 3.3 & 6.7 & 25.5 & 31.8 & 32.7 & 0.768 \\
\hline Valid N (listwise) & 330 & & & & & \\
\hline
\end{tabular}

\begin{tabular}{|c|c|c|c|c|c|}
\hline Interpretation & Always & Often & Sometimes & Rarely & Never \\
\hline Likert scale (1-5) & 5 & 4 & 3 & 2 & 1 \\
\hline RFI & $\begin{array}{c}.80 \text { to } \\
1.0\end{array}$ & $\begin{array}{c}.60 \\
\text { to } .79\end{array}$ & .40 to .59 & .20 to .39 & $\begin{array}{c}.00 \\
\text { to } .19\end{array}$ \\
\hline
\end{tabular}

Explanation: Walking within the campus especially short distances has RFI of .867 which falls within .80 to 1.0 which is associated with 'Always'

4.4.4 Readiness of stakeholders to learning more about greening

Following the views presented in Table 7, many of the respondents ( 88.5 per cent) expect to learn more about 'greening' to promote efficient transportation, save energy, save resource and manage waste generated on FUTA campus. Only a few ( 8.8 per cent) stakeholders seem not to be concerned about protecting their environment. It is believed that the concern and actions of the large proportion who are positive about protecting their environment will eventually motivate others. However, Lacasse (2012) asserted that environmental attitudes are not always altered by performing green behaviours, but attitudes are more likely to change among some people and in certain contexts. The author found that focusing on an array of small and manageable personal behaviours can be a good first step to addressing global climate change issues. Additionally, Siwaporn, et al. (2017) found that voluntary approach only cannot bring about behavioural change, instead, incentive measures will produce a greater positive effect on waste reduction. 
Table 7: Awareness for greening project implementation among stakeholders on FUTA campus

\begin{tabular}{|l|r|r|r|}
\hline & Frequency & Per cent \\
\hline Expectation to learn more about 'greening' & 292 & 88.5 \\
\hline Yes & 29 & 8.8 \\
\hline No & 321 & 97.3 \\
\hline Total & 9 & 2.7 \\
\hline No Response & $\mathbf{3 3 0}$ & $\mathbf{1 0 0 . 0}$ \\
\hline Total & &
\end{tabular}

\subsection{Dimensions of Environmental Awareness}

The purpose of awareness about the environment is to help individuals and group to understand the impact they live on the environment thereby finding a lasting remedy for keeping the surrounding clean and green. Awareness for greening project implementation among students, staff and commercial service providers was measured from three dimensions of environmental motivation, knowledge and skills. One sample t-test which generated the significance values and means were used to present results on awareness for greening project implementation based on the three dimensions highlighted earlier. The latter (mean scores) were applied in the calculation of awareness index for each group of stakeholders. Other opinions of respondents were also analyzed from each group of stakeholder's and general perspectives (see Table 8).

4.5.1 Environmental motivation

Firstly, based on the information presented in Table 8, staff (0.876) and students $(0.837)$ were 'very much aware' of environmental problems while commercial service providers $(0.775)$ were 'moderately aware'. The overall index for all the respondents, 0.839 indicates that stakeholders were generally 'very much aware' of environmental problems and therefore a source of concern for them and this has generated environmental motivation. The statement was significant at 0.01 level. Also, only staff $(0.835)$ were 'very much aware' of what should be done and how to be responsible to the environment, indicating that they were more motivated about what should be done and how to be responsible to the environment than students and commercial service providers who indicated moderately level of awareness each with indexes 0.756 and 0.775 respectively. Though the statement was statistically significant for all the stakeholders, the overall index showed 'moderate awareness' level with value, 0.765. Motivation should produce interest or drive to act positively. Table 8 shows that all the stakeholders' group were 'very much aware' of the need to show interest in acting positively though the index for commercial service providers of 0.888 was a little higher than those of staff and students who recorded 0.822 and 0.825 indexes. This is not unexpected; they more profit-oriented than other stakeholders. They can make some monetary savings by doing so. The overall index of 0.828 showing 'very much awareness' was significant at 0.00 level. Summarily, Environmental motivation is a function of concern about environmental problems, understanding of one's empowerment and understanding of one's responsibilities and willingness to act. This is highest among the staff (0.866), following closely by students $(0.805)$ and lowest among commercial service providers $(0.792)$. Staff should be more motivated to be able to guide other stakeholders accordingly most especially, the students. It is noteworthy that the overall perception of stakeholder on the statement was 0.828 which is interpreted as "very much aware".

4.5.2 Environmental knowledge

Firstly, the staff observed that they are 'very much aware' $(0.812)$ of their environment as they claimed to possess information about environmental problems. Students and commercial service providers' views have values 0.760 and 0.776 respectively to show that their level of knowledge about environmental problems is moderate. The general perception (0.766) showed that they collectively indicated 'moderate awareness' for their level of possessing information about environmental problems. This general perception of the statement was statistically significant at 0.01 . Secondly, all the stakeholders rated their level of awareness about the cause-effect relationships of environmental problems the same way though with differences in indexes. Students, staff and commercial service providers' level of awareness for a cause-effect relationship of the environmental problem were 0.743 , 0.788 and 0.775 correspondingly which means each group of stakeholder's rating fall under 'moderate awareness', the same rating assumed by the generality of the stakeholders (0.748). This value was statistically significant at 0.01 . Thirdly, like the previous statement, Table 8 shows that students, staff and commercial service providers rated their level of awareness on 'knowing what to do to protect the environment as 'moderate awareness'. Their indexes were $0.739,0.788$ and 0.775 respectively. As expected, the general perception was 'moderate awareness' with an index of 0.745 which is statistically significant at 0.01 level. Summarily, Environmental Knowledge as discussed above embraces information about environmental problems, knowledge of the cause-effect relationships of environmental problems and knowing what to do to protect our environment and was highest among the staff $(0.796)$, followed by commercial service providers $(0.775)$ and then students $(0.747)$ and rate 'moderate awareness" by all the groups. 


\subsubsection{Environmental skills}

Environmental skills can be regarded as the product of both environmental motivation and environmental knowledge. It contributes to actual undertaken of environmental protection actions. Skills for waste, transport and energy management activities to protect the environment has indexes, 0.780 and 0.725 among students and commercial service providers which showed 'moderate awareness' level against 'very much aware' showed by the staff $(0.835)$. The overall index regarding the statement was 0.784 which equates to 'moderate awareness' and significant at 0.01 level.

Additionally, possession of skills for environmental protection habits and deliberate action was highest for staff $(0.818)$ at 'very much aware' level, followed by students $(0.768)$ and services providers $(0.725)$ at 'moderately aware' level each. All the respondents were 'moderately aware' $(0.772)$ that they possess environmental protection habits and deliberate actions and the statement was statistically significant at 0.01 level. To be practical about the possession of environmental skills, FUTA sampled stakeholders were asked whether they undertake some of the environmental initiatives identified earlier in table 4.3 despite some inconveniences. Each group of stakeholders were 'moderately aware' that they undertake some of the activities in Table 6 despite some inconveniences. Indexes were in the following descending order: commercial service providers $(0.775)$, staff $(0.771)$, and students $(0.724)$ which shows that commercial service providers appear to be more involved in practical actions to protect the environment compare to others. A statistically significant score of 0.730 which shows 'moderate awareness' was arrived at for all the respondents. Summarily, environmental skills which consist in personal abilities to act at different areas (waste, transport and energy management), environmental protection habits and deliberate action and actual undertaking of some of the greening activities was highest for staff $(0.808)$ and lower for students $(0.757)$ and lowest for commercial service providers $(0.742)$ in that arrangement but on the average, the index was 0.762 . 4.5.4 Environmental Awareness Index (EAI)

Environmental Awareness Index (EAI) was calculated for each group of stakeholders by calculating the arithmetic mean of indexes for all the items in the table in each stakeholder's group column as presented in Table 8 . At stakeholders' level staff $(0.823)$ are more environmentally aware than both students $(0.770)$ and commercial service providers $(0.769)$ while students are more environmentally aware than commercial service providers. It seems the staff members are being a good example to other stakeholders in this area since they are the most environmentally aware among the three stakeholders. They seem to probably translate that to the subconscious state of the students who also demonstrated a significant level of awareness compared to the commercial service providers who are also closely aware. This action, however, may not be deliberate but through unconscious actions like making soft copy lecture notes available to the class, online submission of assignment, creation group chat for project student among others. A recent study by Ramesh (2017) found fair awareness level of green campus in the areas of water and waste management, renewable energy, green building, paperless office and Wifi Campus on the campus sampled though the found that this has not translated into conscious actions among most stakeholders based on what can be deduced from their behavioural conducts over time to sustain the 'living environment'. This is akin to the findings in the study conducted by Dahle and Neumayer (2001) which shows that though institution studied was not at ground zero concerning greening, overall environmental quality is relatively poor. Robert, et al. (2010) observed that 'high sustainability' companies are found to be more likely to have established processes for stakeholder engagement, to be more long-term oriented and able to outperform their counterparts within the same period.

Based on the three dimensions of environmental awareness, environmental motivation among all the stakeholders was the highest. Stakeholders have the environmental motivation of 0.811 which is higher than their environmental knowledge and environmental skills. Their environmental skills (0.762) also weigh higher than environmental knowledge (0.753). Respondents appear to be prepared to act even with their moderate knowledge about an environmental problem. Hassan, Noordin and Sulaiman (2010) found that being aware of the responsibility to the environment does not necessarily translate into having the ability to relate its aspects, such as social, economy and energy sources with the environmental protection issues. According to Hassan, et al. (2010), environmental awareness concept on sustainable development can only be achieved through education (formal and informal) which should fulfil four objectives as proposed by UNESCO including knowledge, awareness, skills, and participation. They further found that there is a relationship between the level of environmental awareness in the concept of sustainable development and the practices, attitudes and moral values of sustainability. 
Table 8: Environmental Awareness among Stakeholders on FUTA campus

\begin{tabular}{|c|c|c|c|c|c|c|c|}
\hline & \multicolumn{4}{|c|}{ Awareness Level Index } & \multirow[b]{2}{*}{$\mathrm{T}$} & \multirow[b]{2}{*}{ df } & \multirow{2}{*}{$\begin{array}{l}\text { Sig. (2- } \\
\text { tailed) }\end{array}$} \\
\hline & Students & Staff & $\begin{array}{c}\text { Commercial } \\
\text { service providers }\end{array}$ & All & & & \\
\hline Environmental motivation & 0.805 & 0.866 & 0.792 & 0.811 & - & - & - \\
\hline $\begin{array}{l}\text { I am aware of environmental } \\
\text { problems }\end{array}$ & 0.837 & 0.876 & 0.775 & 0.839 & 73.04 & 287 & .000 \\
\hline $\begin{array}{l}\text { I am aware of what should be done } \\
\text { and how to be responsible to the } \\
\text { environment }\end{array}$ & 0.756 & 0.835 & 0.775 & 0.765 & 61.82 & 287 & .000 \\
\hline I have interest in acting positively & 0.822 & 0.888 & 0.825 & 0.828 & 72.18 & 287 & .000 \\
\hline Environmental knowledge & 0.747 & 0.796 & 0.775 & 0.753 & & & \\
\hline $\begin{array}{l}\text { Information about environmental } \\
\text { problems }\end{array}$ & 0.760 & 0.812 & 0.775 & 0.766 & 61.72 & 287 & .000 \\
\hline $\begin{array}{lll}\text { Cause-effect relationships } & \text { of } \\
\text { environmental problems }\end{array}$ & 0.743 & 0.788 & 0.775 & 0.748 & 63.09 & 287 & .000 \\
\hline $\begin{array}{l}\text { Knowing what to do to protect our } \\
\text { environment }\end{array}$ & 0.739 & 0.788 & 0.775 & 0.745 & 59.65 & 287 & .000 \\
\hline Environmental skills & 0.757 & 0.808 & 0.742 & 0.762 & & & \\
\hline $\begin{array}{l}\text { Waste, transport and energy } \\
\text { management activities to protect the } \\
\text { environment }\end{array}$ & 0.780 & 0.835 & 0.725 & 0.784 & 67.23 & 287 & .000 \\
\hline $\begin{array}{l}\text { Environmental protection habits and } \\
\text { deliberate action. }\end{array}$ & 0.768 & 0.818 & 0.725 & 0.772 & 65.21 & 287 & .000 \\
\hline $\begin{array}{l}\text { Undertakes some of the actions in } \\
\text { Q9 despite some inconveniencies }\end{array}$ & 0.724 & 0.771 & 0.775 & 0.730 & 60.46 & 287 & .000 \\
\hline EAI & 0.770 & 0.823 & 0.769 & - & - & - & - \\
\hline Valid N (listwise) & 288 & 34 & 8 & 330 & - & - & - \\
\hline Interpretation of index & \multicolumn{2}{|c|}{$\begin{array}{l}5 \text {-Very much } \\
\text { aware }\end{array}$} & $\begin{array}{l}\text { 4-Moderately } \\
\text { aware }\end{array}$ & \multicolumn{2}{|c|}{$\begin{array}{l}\text { 3-Somewhat } \\
\text { aware }\end{array}$} & $\begin{array}{l}\text { 2-Slightly } \\
\text { aware }\end{array}$ & $\begin{array}{l}1-\text { Not at } \\
\text { all aware }\end{array}$ \\
\hline & \multicolumn{2}{|c|}{.80 to 1.0} & .60 to .79 & \multicolumn{2}{|c|}{.40 to .59} & .20 to .39 & .00 to .19 \\
\hline
\end{tabular}

4.5.5 Testing of hypotheses

The tested hypothesis is as stated below.

$\mathrm{H}_{1}$ : There is no significant difference in the stakeholders' awareness level for greening project initiatives in the study area

This hypothesis was tested using the Kruskal-Wallis test. The test is the non-parametric alternative to a Oneway between-groups analysis of variance. It allows the study to compare the scores on some continuous variable for three or more groups (Pallant, 2011). The test result is much less sensitive to outliers and does not assume normality as required by one-way ANOVA which the data does not meet. However, to properly analyze its results, one must determine whether the distribution of data for each group (i.e. the distribution of scores for independent variables-students, staff and commercial service providers) have the same shape (that is, the same variability). One can only use Kruskal-Wallis test to compare the means of a group of stakeholders if the distribution of scores for independent variables shows different shapes, otherwise, median must be utilized for comparison (Leard, 2018). To confirm this, normal distribution histograms were drawn as shown in Figures 1, 2 and 3. The distribution of the independent variables as shown by the figures have different shapes and variabilities, hence, the use of mean for comparison.

The test results displayed in Table 9 revealed that there is no statistically significant difference in the level of awareness for greening project implementation among major stakeholders in the study area (students, $n=288$, staff, $n=33$, commercial service providers, $n=9) X^{2}(n=330)=3.909, p=.142$. This means that the null hypothesis $\left(H_{01}\right)$ which states that there is no significant difference in the stakeholders' awareness level for greening project initiatives in the study area should be accepted. Stakeholders show no major difference in their level of awareness for greening project implementation of FUTA campus. Notwithstanding, members of staff recorded a higher mean score $(X=196.59)$ than the other two stakeholders. Students (162.08) also have a higher mean score compare to commercial service providers (161.06). This result further confirms the finding in objective one which shows that staff have the highest environmental awareness index and while the commercial service providers have the least. A related study by Sivamoorthy, et al (2013) shows that the level of awareness was generally high among the respondents but in practice, males were more involved than females whereas the pilot study conducted by Akkor and Gunduz (2018) indicates that female students have higher environmental attitudes and they are more 
sensitive to the environment than male students.

Table 9. Kruskal-Wallis Test

\begin{tabular}{|l|l|r|r|}
\hline \multicolumn{2}{|c|}{ Ranks } & N & Mean Rank \\
\hline & Category & 288 & 162.08 \\
\hline \multirow{4}{*}{ Awareness } & Student & 33 & 196.59 \\
\cline { 2 - 4 } & Academic staff & 9 & 161.06 \\
\cline { 2 - 4 } & Others & 330 & \\
\cline { 2 - 4 } & Total & & \\
\hline
\end{tabular}

\begin{tabular}{|l|r|}
\hline Test Statistics, $\mathbf{a}, \mathbf{b}$ & Awareness \\
\hline Chi-Square & 3.909 \\
\hline Df & 2 \\
\hline Asymp. Sig. & .142 \\
\hline a. Kruskal Wallis Test & \\
\hline b. Grouping Variable: Category & \\
\hline
\end{tabular}

\section{Conclusion}

The study has assessed the familiarity of major campus stakeholders with the term 'greening' or 'environmental sustainability/protection'; examined the frequency of participation of stakeholders in existing greening activities, and investigated the dimensions of environmental awareness among stakeholders in the study area using a participatory action approach to generate knowledge on the topic to produce the needed commitment to environmental protection. It can be concluded that seventy of every one hundred university stakeholders are to a great extent familiar with the related to greening. Stakeholders often use greening initiatives associated with efficient transportation, efficient energy and waste management consciously or otherwise. The study revealed that stakeholders' readiness to learn more about the initiatives is believed to be a pre-requisite for better environmental management. Environmental motivation, environmental knowledge and environmental skills are highest for staff, higher for student and high for commercial service providers on the campus. Well-informed stakeholders can foster a university campus where all are at their best in promoting the implementation of greening initiatives in the areas of community services, training, research and campus operations to deliver environmental, social and economic benefits to individuals and the institution in general. It is suggested that available media such as campus customized mail, bulletin, annual conferences and lectures and radio should be used to sensitize both internal and external stakeholders on the importance and benefits of greening and common initiatives that can help in achieving substantial progress. Above and beyond a few instances where students have the opportunity to learn about their environment, the institution should include a general course for first-year students on environmental sustainability. This is one way of inculcating the common principle of sustainability such as moral obligation, sustainable physical operations, sustainability in research and public awareness on campus among stakeholder stakeholders, most especially, the students who are being raised to become future decision-makers.

\section{References}

Abubarkar, I. R., Al-Shihri, F. S. \& Ahmed, S. M. (2016). Students' assessment of campus sustainability at the University of Dammam, Saudi Arabia and evidence. Sustainability, 7 (59), 1-14.

Akinbamijo, B. O. \& Osunsanmi, G. (2007). Access in cities and sustainable urban transport-a challenge for third world city planning practice. Pakistan Journal of Social Sciences. 4 (5), 654-661.

Akkor, O. \& Gunduz, S. (2018). The study of university students' awareness and attitude towards environmental education in Northern Cyprus. EURASIA Journal of Mathematics, Science and Technology Education, 14(3), 1057-1062.

Beringer, A.; Adomßent, M. (2008). Sustainable university research and development: Inspecting sustainability in higher education research. Environ. Educ. Res., 14, 607-623.

Cole, L. (2003). Assessing sustainability on Canadian university campuses: development of a campus sustainability assessment framework.

Creighton, S. H. (1999). Greening the Ivory tower. Improving the environmental track record of universities, colleges, and other institutions. Cambridge (Mass): MIT Press.

Dahle, M. \& Neumayer, E. (2001). Overcoming barriers to campus greening: a survey among higher educational institutions in London, UK. International Journal of Sustainability in Higher Education, 2 (2), 139-160.

Dookhitram, K., Narsoo, J., Sunhaloo, M. S., Sukhoo, A. \& Soobron, M. (2012). Green computing: An awareness survey among university of technology, Mauritius students. 3 (1), 256-260.

Dookhitram, K., Narsoo, J., Sunhaloo, M. S., Sukhoo, A. \& Soobron, M. (2012). Green computing: An awareness survey among university of technology, Mauritius students. 3 (1), 256-260. 
Federal Ministry of Environment (2016). Nigeria National Policy on Environment.

FIlho, W. L., Shiel, C. \& Paco, A. (2015). Putting sustainable development in practice: campus greening as a tool for institutional sustainability efforts.

Fu, L., Zhang, Y. \& Bai, Y. (2018). Pro-environmental awareness and behaviours on campus: evidence from Tianjin, China. EURASIA Journal of Mathematics, Science and Technology Education, 14(1):427-445: DOI: 10.12973/ejmste/77953.

Hamid, S., Ijab, M. T., Sulaiman, H. Anwar, R., \& Norman, A. A. (2017). Social media for environmental sustainability awareness in higher education. International Journal of Sustainability in Higher Education, 18 (4), 474-491.

Harju-Autti, P. (2013). Measuring Environmental Awareness in Nineteen States in India. Universal Journal of Environmental Research and Technology, 3 (5), 544-554.

Heijer, A., Teeuw, P. \& Aalbers, K. (2010). Towards a sustainable campus visions for the future of higher education. Knowledge Collaboration \& Learning for Sustainable Innovation ERSCP-EMSU conference, Delft, The Netherlands, October 25-29.

Ian, T. (2006). Education for Sustainability - Sustainability and Universities. In Encyclopedia of Life Support Systems (EOLSS). Retrieved from http://www.eolss.net/Eolss-sampleAllChapter.aspx

Jadhav, A. S., Jadhav V. V. \& Raut P. D. (2014). Role of Higher Education Institutions in Environmental Conservation and Sustainable Development: A case study of Shivaji University, Maharashtra, India. Journal of Environment and Earth Science, 4 (5), 30-34.

Kokkinen, E. (2013). Measuring environmental awareness in the world (Unpublished Master's thesis). University of Oulu.

Krejcie, R. V. \& Morgan, D. W. (1970). Determining sample size for research activities. Educational and psychological measurement, 30, 607-610.

Lacasse, K. (2012). Policy analysis: Addressing the "go green" debate: policies that encourage small green behaviours and their political spillover effects. The Journal of Science Policy \& Governance, 3(1).

Laerd Statistics (2018). IBM SPSS Statistics Guide. https://www.statistics.laerd.com

Lally, P., Van Jaarsveld, C. H. M., Potts, W. W. \& Wardle, J. (2010). How are habits formed: Modelling habit formulation in the real world. European Journal of Social Psychology. 40, 988-1009.

Leal Filho, W., MacDermot, F., and Padgam, J. (eds) (1996). Implementing Sustainable Development at University Level - A Manual of Good Practice. CRE-COPERNICUS, Bradford.

McMillan, J.; Dyball, R. (2009). Developing a Whole-of-University Approach to Educating for Sustainability. J. Educ. Sustain. Dev. 3, 55-64.

Mruszczyk, A., Polido, F., Rey López, J.A., Skelton, K., Virta, A., \& Wagner, F., (2009). Towards a sustainable university green paper for the University of Jyväskylä. (Project work). University of Jyväskylä, Finland.

Ngniatedema, T. \& Li, S. (2014). Green operations and organizational performance. International Journal of Business and Social Science, 5(3), 50-58. Center for Promoting Ideas, USA. www.ijbssnet.com.Ramesh, K. (2017). Awareness about green campus opportunities amongst the educational institutions of north Karnataka. International Journal of Commerce and Management Research, 3(3), 79-82.

Oyelude, A. A. \& Alabi, A. O. (2013). Greening: Pluses and minuses of Nigerian libraries in promoting environmental sustainability. IFLA WLIC. Retrieved from: http://creativecommons.org/licenses/by/3.0/

Pallant, J. (2011). SPSS survival manual: A step by step guide to data analysis using SPSS (4th ed). Australia: Allen \& Unwin.

Raderbauer, M. (2011). The importance of sustainable business practices in the Viennese (Unpublished master's thesis). University of Exeter.

Ramesh, K. (2017). Awareness about green campus opportunities amongst the educational institutions of north Karnataka. International Journal of Commerce and Management Research, 3(3), 79-82.

Robert G. E., Ioannis, I., \& George S. (2010). The impact of corporate sustainability on organizational processes and performance.

Sahu, U., Roy, M. \& Rajkiran, M. (2015). Environmental awareness among undergraduate students in rural area. IOSR Journal of Environmental Science, Toxicology and Food Technology (IOSR-JESTFT), 1(4), 27-32.

Sivamoorthy, M., Nalini, R., \& Satheesh, K. (2013). Environmental awareness and practices among college students. International Journal of Humanities and Social Science Invention, 2(8), 2319 - 7722.

Siwaporn, T., Vilas, N., Brahmanand, M. \& Chettiyappan, V. (2017). Greening of a campus through waste management initiatives: Experience from a higher education institution in Thailand. International Journal of Sustainability in Higher Education, 18(2), 203-217.

Tiyarattanachai, R. \& Hollmann, N. M. (2016). Green campus initiative and its impacts on quality of life of stakeholders in green and non-green campus universities. SpringerPlus. pp. 5-84.

Wright, T. S. (2002). Definitions and frameworks for environmental sustainability in higher education. High. Educ. Policy, 15, 105-120. 
Histogram

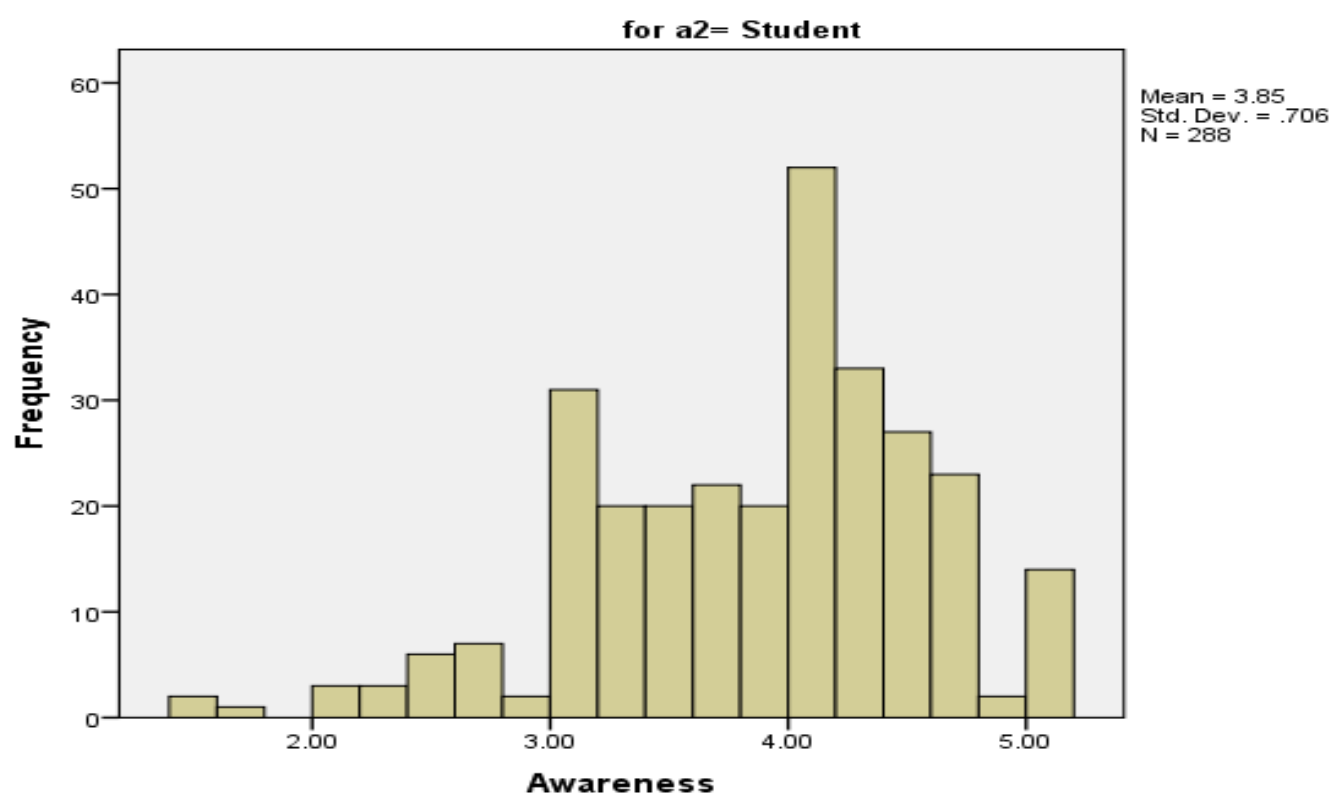

Figure 1: Variability of the level of awareness for greening among students Histogram

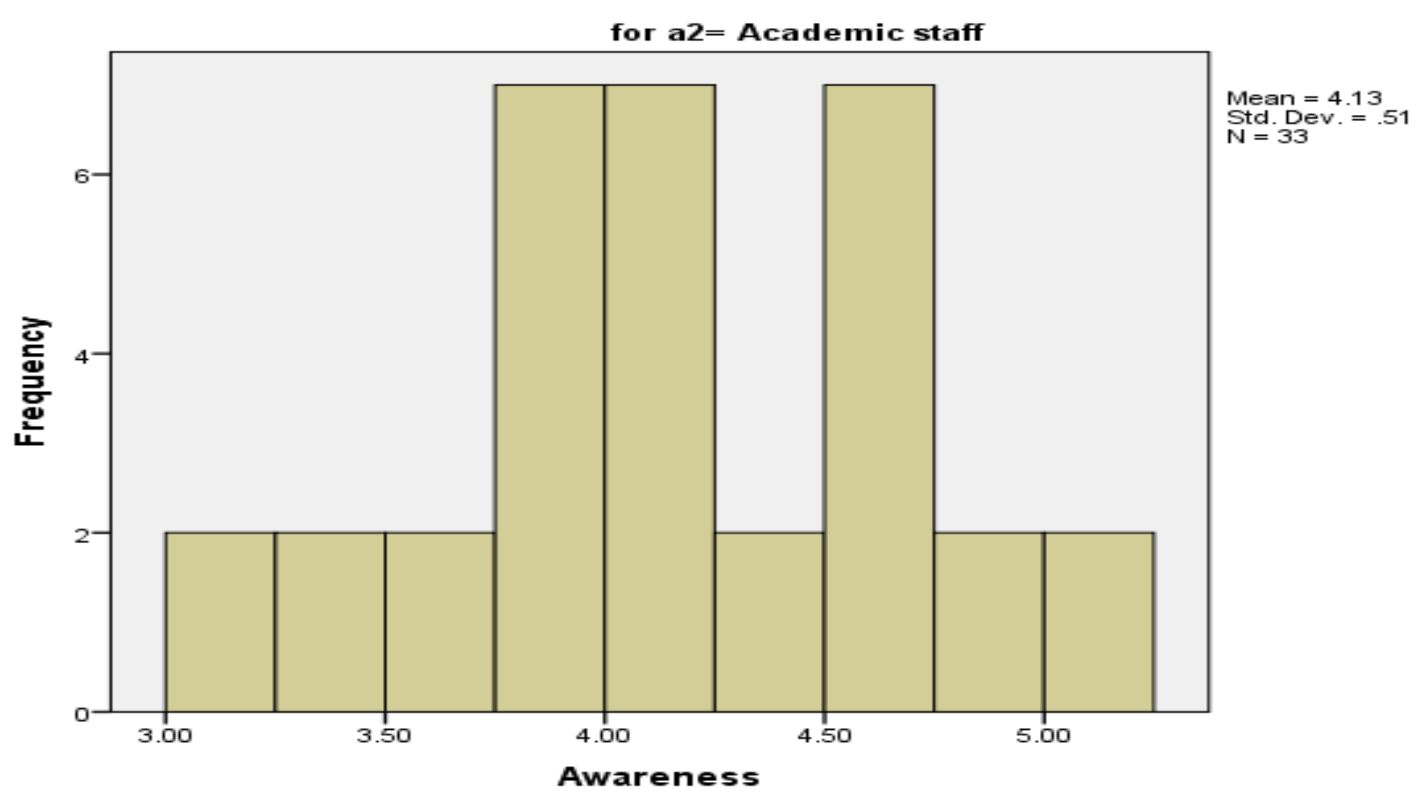

Figure 2: Variability of the level of awareness for greening among staff 


\section{Histogram}

for $a 2=$ others

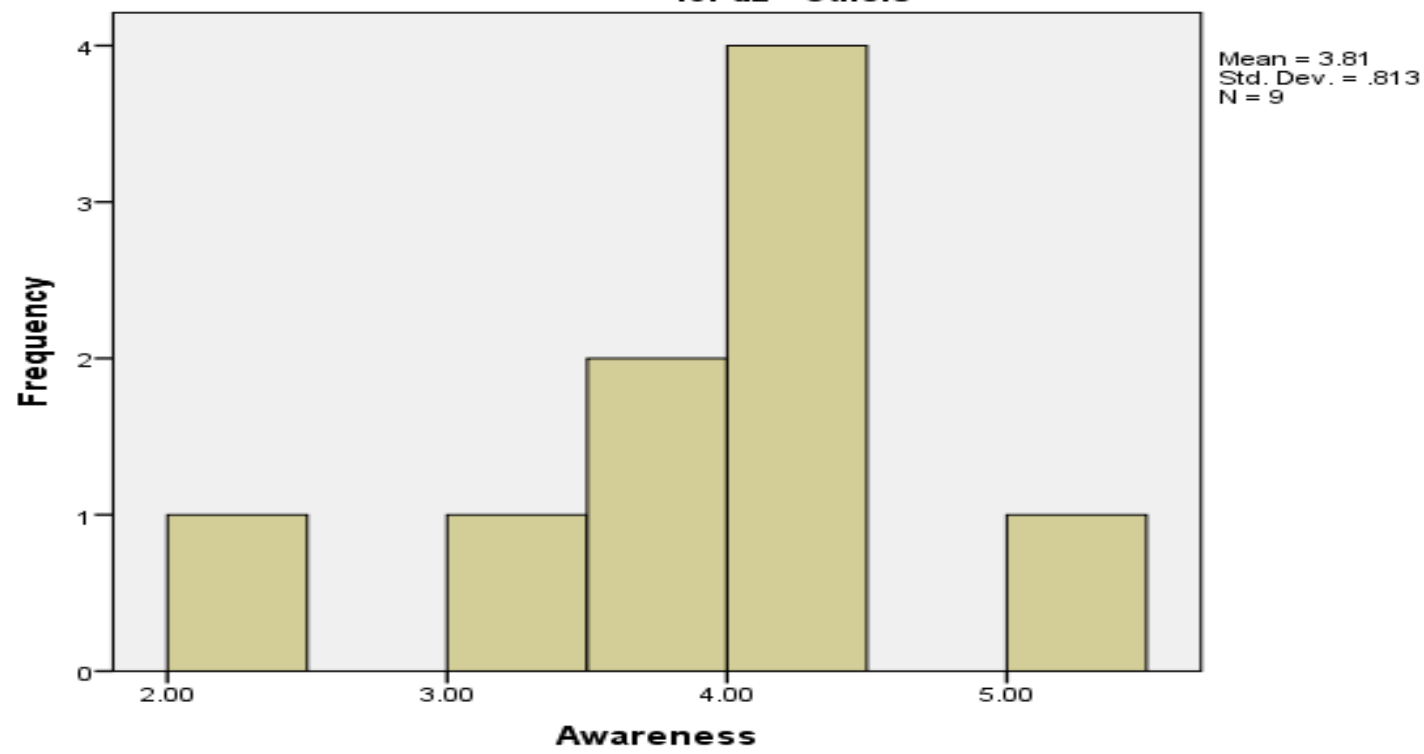

Figure 3: Variability of the level of awareness for greening among commercial service providers 